\title{
Significantly elevated number of human infections with H7N9 virus in Jiangsu in eastern China, October 2016 to January 2017
}

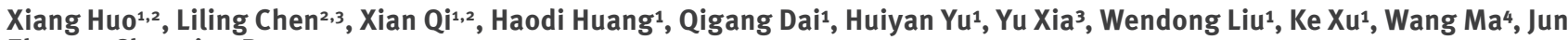

Zhang ${ }^{3}$, Changjun $\mathrm{BaO}^{1}$

1. Jiangsu Provincial Center for Disease Control and Prevention, Nanjing, China

2. These authors contributed equally to this work

3. Suzhou Center for Disease Control and Prevention, Suzhou, China

4. Nanjing Medical University, Nanjing, China

Correspondence: Chang-jun Bao (ba02000_cn@163.com)

Citation style for this article:

Huo X, Chen L, Qi X, Huang H, Dai Q, Yu H, Xia Y, Liu W, Xu K, Ma W, Zhang J, Bao C. Significantly elevated number of human infections with H7N9 virus in Jiangsu in eastern China, October 2016 to January 2017. Euro Surveill. 2017;22(13):pii=30496. DOI: http://dx.doi.org/10.2807/1560-7917.ES.2017.22.13.30496

Since first identified in 2013 , the $\mathrm{H}_{7} \mathrm{~N} 9$ virus has caused several waves of human infections in China, with a current wave including a number of patients with very severe disease. Jiangsu is one of the most impacted provinces, whereby as of 31 January 2017, the number of human infections $(n=109)$ in the ongoing fifth $\mathrm{H}_{7} \mathrm{~N}_{9}$ wave has exceeded the sum of those in the four preceding ones. Ten of 13 cities in Jiangsu have been affected, and clustered infections as well as one co-infection with seasonal influenza have been observed. With a median age of 58 years and $74.3 \%$ $(81 / 109)$ of patients being male, the characteristics of cases are similar to those in previous waves, however patients with $\mathrm{H}_{7} \mathrm{~N}_{9}$ seem to have an accelerated disease progression. Preliminary case fatality remains above $30 \%$. No significant viral mutations have been found in key functional loci. Environmental $\mathrm{H}_{7} \mathrm{~N} 9$ detection rate and number of days with high risk ambient temperatures were both significantly elevated during the month of December 2016 when most human infections were reported. A number of municipal governments in Jiangsu have implemented live poultry market closures to impede viral transmission to humans. A detectable decline in human infections has been observed in these municipalities and the entire province since January 2017.

\section{Introduction}

Avian influenza viruses cause human infections continuously worldwide. Compared with other viruses, such as $\mathrm{H}_{5} \mathrm{~N}_{1}, \mathrm{H}_{5} \mathrm{~N} 6, \mathrm{H}_{9} \mathrm{~N}_{2}$ and $\mathrm{H}_{7} \mathrm{~N}_{7}$, the $\mathrm{H}_{7} \mathrm{~N}_{9}$ virus is much more potent due to its better ability to cross the species barriers and infect both poultry and humans, and this has raised serious concerns for potential pandemics [1]. As of 16 January 2017, a total of 918 laboratory-confirmed cases of human infection with $\mathrm{H}_{7} \mathrm{~N}_{9}$ virus in China have been reported to the World Health
Organization (WHO) in less than four years (since March 2013) [2]. In contrast, at the same date, and for a period of over 13 years (since 2003) the number of $\mathrm{H}_{5} \mathrm{~N} 1$ cases worldwide was only 856 [2].

Since its first identification in March 2013, the $\mathrm{H}_{7} \mathrm{~N}_{9}$ virus has caused five waves of human infections in China [3]. There were 134 cases, 304 cases, 219 cases and 118 cases detected and reported in the first four waves, respectively, with a declining trend in incidence [4]. However, the fifth wave (since September 2016) surged with a steep increase in case numbers from 1 December 2016, and 106 cases were reported in December 2016 alone. As of 31 December 2016, the number of reported cases in the fifth wave was 11.4 , 2.7 and 6.1 times that of the corresponding periods in the second (10 cases), third (31 cases) and fourth (16 cases) waves, respectively. Seven provinces in China have been affected, with Jiangsu being one of the most impacted [3]. Overall, the majority of reported human infections occurred in older males (median age: 57 years). The general case fatality was around 41\% [4]. Here we describe the current fifth wave of human infections with $\mathrm{H}_{7} \mathrm{~N} 9$ in Jiangsu province, which was characterised by a significantly elevated incidence in a wider affected area. Factors potentially contributing to the epidemic, such as meteorological factors, environmental detection rates of $\mathrm{H}_{7} \mathrm{~N}$, and viral mutations, are also explored and discussed.

\section{Methods}

Human surveillance

In China, all laboratory-confirmed human infections with $\mathrm{H}_{7} \mathrm{~N} 9$ are reported through a national system for reporting of notifiable infectious diseases [5]. In Jiangsu province, respiratory samples from suspected 
Number of human cases due to H7N9 and positivity rate of environmental samples for H7N9 in Jiangsu province, 2013-31 January 2017 ( $n=213$ cases)

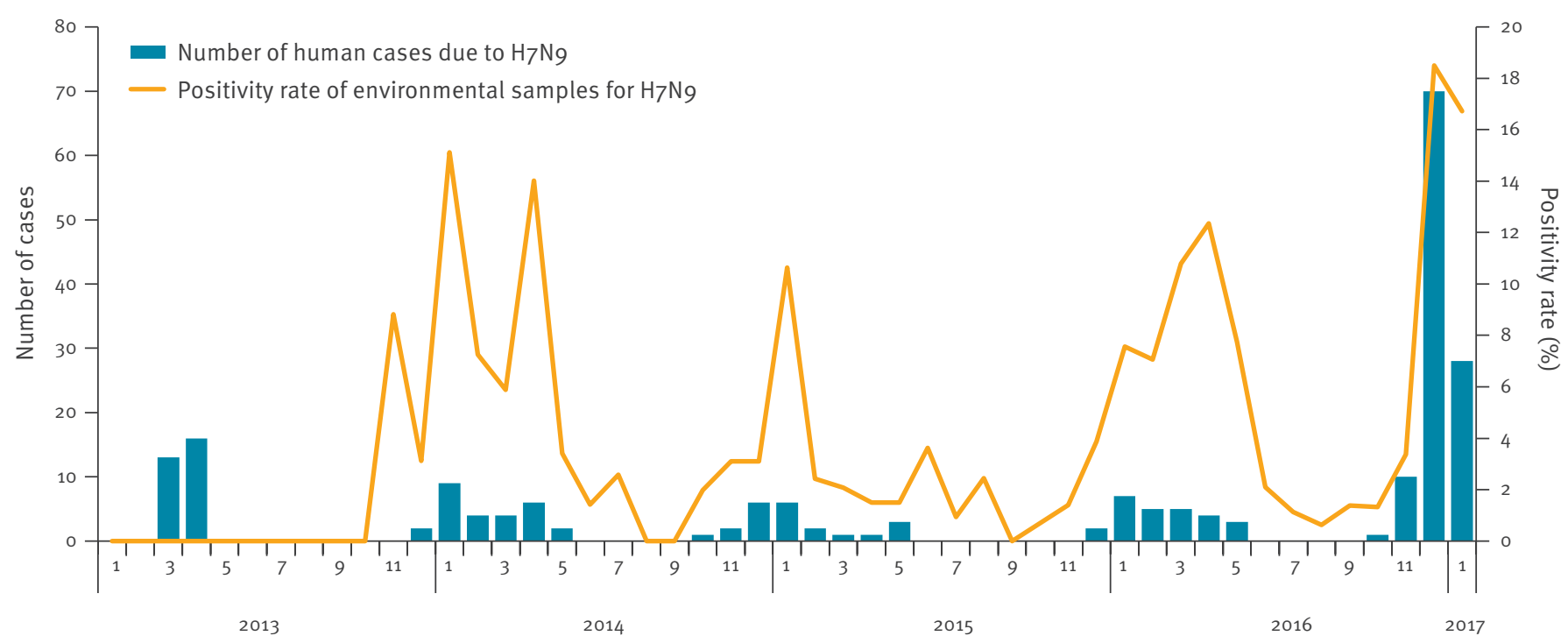

Month/year

$\mathrm{H}_{7} \mathrm{~N} 9$ patients are tested for $\mathrm{H}_{7} \mathrm{~N} 9$ virus as well as common types of seasonal influenza (such as $\mathrm{H}_{1} \mathrm{~N}_{1}$, $\mathrm{H}_{3} \mathrm{~N}_{2}$ and B) by local municipal Centers for Disease Control and Prevention (CDC) using real-time PCR. The $\mathrm{H}_{7} \mathrm{~N} 9$ avian influenza nucleotide test kits (bioPerfectus technologies, Taizhou, China) are most commonly used. The demographic, epidemiological and clinical information of patients infected with $\mathrm{H}_{7} \mathrm{~N}_{9}$ is collected using standardised questionnaires by local Centers for Disease Control and Prevention (CDC) staff, or trained clinical doctors, and reported to jiangsu Provincial $C D C$ and China CDC through this system. Jiangsu Provincial CDC is responsible for checking and monitoring the reported information and takes part in the patients' investigations if necessary. According to the Diagnosis and Treatment Scheme published by the National Health and Family planning commission of China, patients with pneumonia and either respiratory failure or any other organ dysfunction are considered as severe infections.

All patients infected with $\mathrm{H}_{7} \mathrm{~N} 9$ as of 31 January 2017 in Jiangsu province $(n=213)$ were included in this study. All the positive samples (confirmed by real-time PCR) collected from $\mathrm{H}_{7} \mathrm{~N} 9$ patients were sent by local municipal CDCs to Jiangsu Provincial CDC, where the viruses were isolated and sequenced according to a previously described procedure [6].

\section{Environmental surveillance}

Aiming to predict and assess risk of human infections, a surveillance on avian influenza virus in avian-associated sites, such as poultry farms, live poultry whole sale and retail markets, has been routinely conducted year-round in Jiangsu province since October 2013. The surveillance sites cover all 13 cities of Jiangsu province. An average of three to eight sites are covered monthly in each city, where swab samples of avian faeces, cages, or drinking water of birds and poultry for sale, are collected by each municipal CDC. All the samples are tested for avian influenza using real-time PCR by municipal CDCs and then results are reported to Jiangsu Provincial CDC.

\section{Meteorological factors}

Air temperature has been previously reported to be associated with human infection with $\mathrm{H}_{7} \mathrm{~N} 9$ virus, and higher risk of human infection was found when daily minimum temperatures range from ca 5 to $9^{\circ} \mathrm{C}$ and when daily maximum temperatures are between ca 13 to $18^{\circ} \mathrm{C}$ [7]. To investigate if air temperatures in Jiangsu might have been favourable to human infections during the fifth $\mathrm{H}_{7} \mathrm{~N} 9$ wave, daily meteorological data provided by Jiangsu Provincial Meteorological Service Center were investigated.

\section{Phylogenetic analysis}

The haemagglutinin (HA) nt sequences were edited and assembled using SeqManPro (DNASTAR,Madison,WI). ClustalXv.2.1 was used for the alignment of $n t$ sequences [8]. A phylogenetic tree of the $\mathrm{HA}_{1}$ coding nt sequences was generated by Molecular Evolutionary Genetic Analysis (MEGA) version 6.06 [9] using a neighbour-joining method with 1,000 bootstrap replicates. We acknowledge the authors, originating and submitting laboratories of the sequences from the EpiFlu Database of the Global Initiative on Sharing Avian Influenza Data (GISAID) (Table 1). 
Location of Jiangsu province in eastern China, with neighbouring provinces (A) and geographical distribution of human infections with H7N9 in Jiangsu province (B), China, 2013-2017

A.

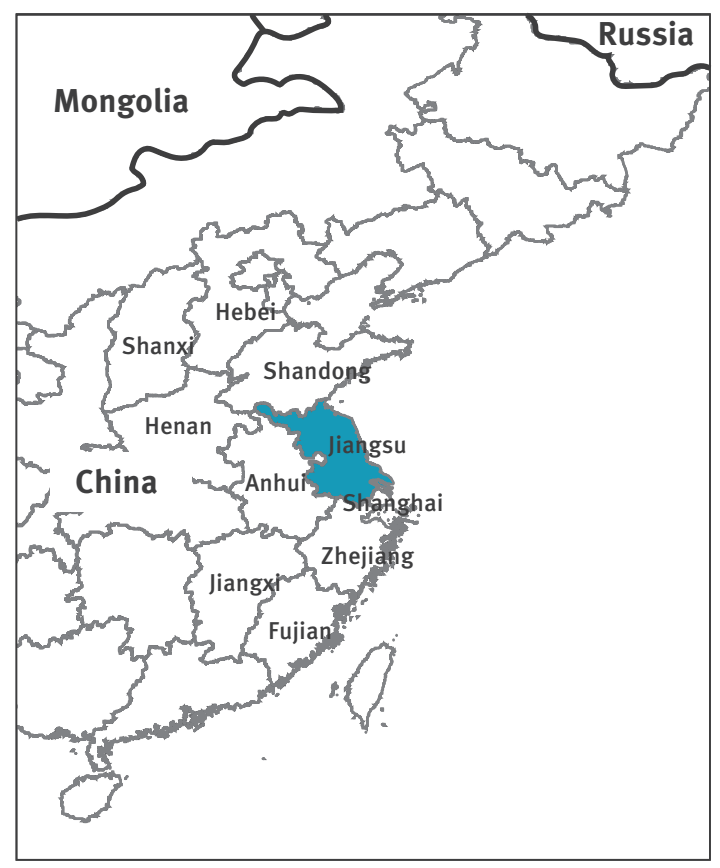

B.

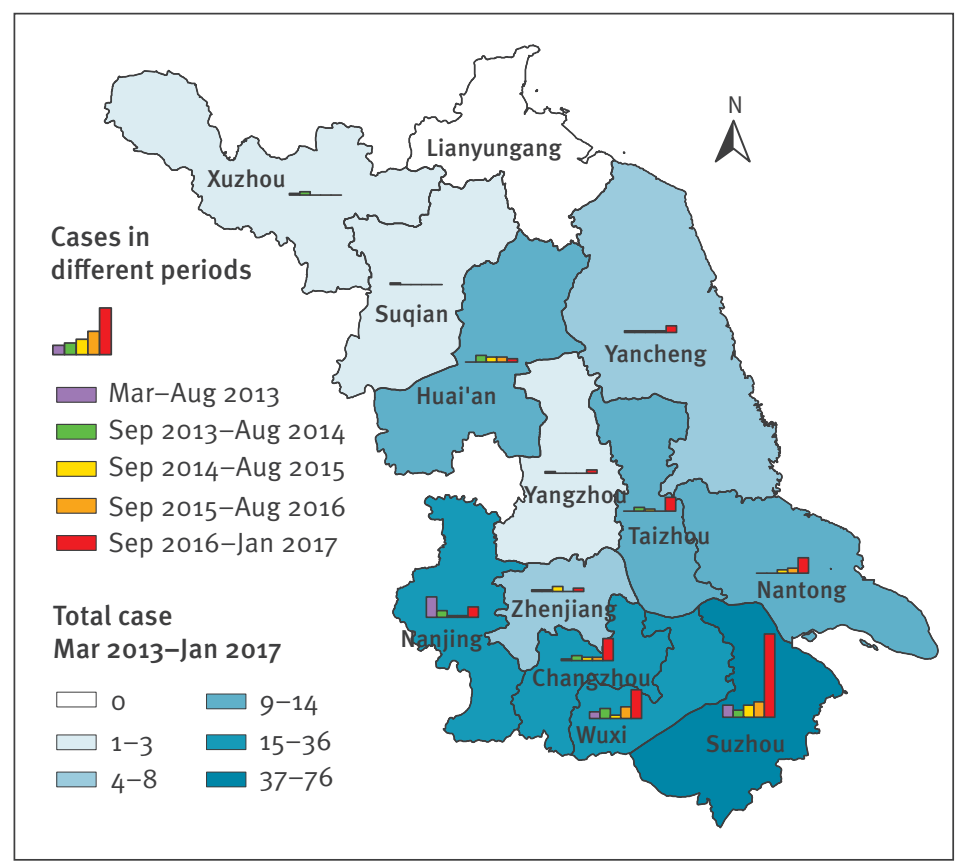

\section{Ethical statement}

The National Health and Family Planning Commission decided that the collection of data from cases of $\mathrm{H}_{7} \mathrm{~N} 9$ was part of the public health investigation of the emerging outbreak, and thus the investigation was exempt from institutional review board assessment [10]. The dataset was anonymised in the national reporting system except for individuals with special access, and was anonymised before data analyses.

\section{Statistical analysis}

Median and interquartile ranges (IQRs) were calculated for continuous variables and absolute numbers and proportions for categorical variables. Selected demographic, epidemiological and clinical characteristics of $\mathrm{H}_{7} \mathrm{~N} 9$ patients were compared among five epidemic waves (March to April in 2013, December 2013 to May 2014, October 2014 to May 2015, December 2015 to May 2016 and October 2016 to 31 January 2017). Pearson chi-squared test was used for comparing proportions and continuity correction or Fisher's exact test was used if appropriate. Kruskal-Wallis $\mathrm{H}$ test was used for comparing medians among multiple groups. Statistical analyses were conducted using $R$ version 3.0.2 and statistical significance level was set at $\leq 0.05$. The hierarchical colour map was produced with ArcGIS software version 10.0 (ESRI, Redlands, CA, US) to state the spatial patterns of human infections with $\mathrm{H} 7 \mathrm{~N}$. All cases with missing data on a certain characteristic were excluded when this characteristic was analysed. Information of total and missing data for each studied variable is shown in detail in Table 2.

\section{Results}

\section{Human infections}

Jiangsu province is now experiencing the fifth wave of human infections with $\mathrm{H}_{7} \mathrm{~N}$. As of 31 January 2017, the cumulated number of cases in the current wave is 109 (since October 2016), which is overwhelmingly higher than in each of the previous four waves $(29,27,22$ and 26 , respectively). The peak monthly incidence in the fifth epidemic is also higher than in the previous waves (70 vs 16, 9, 6 and 7) (Figure 1).

Among recorded cases, 36 died. During the same period, a total of 305 patients were reported nationally, with 98 deaths. Patients of Jiangsu accounted for $35.7 \%(109 / 305)$ of those in the entire country, and this proportion was higher than in previous waves $(8.9 \%-$ $22.0 \%, p<0.0001)$. The preliminary case fatality rate, as there were 36 patients still hospitalised at the time of this analysis, was $33.0 \%(36 / 109)$ in Jiangsu, which is slightly higher than that of the rest of China $(31.6 \%$, $62 / 196)$. Ten of 13 cities in Jiangsu province reported human infections during the fifth wave, which is also more than previously (7-9 cities). Most of the cases were reported from Suzhou (49/109, 45.0\%), Wuxi $(17 / 109,15.6 \%)$ and Changzhou (13/109, 11.9\%). These three cities are adjacent and all located in southern Jiangsu province (Figure 2).

In the fifth wave in Jiangsu province, male patients accounted for $74.3 \% \quad(n=81)$ of the reported 109 patients, and the overall median age was 58 years. 


\section{FIGURE 3}

Phylogenetic analysis of haemagglutinin (HA) sequences of H7N9 viruses derived from patients reported from October to December 2016 in Jiangsu province and H7N9 and H7N3 HA sequences identified earlier in China, 1996-2016

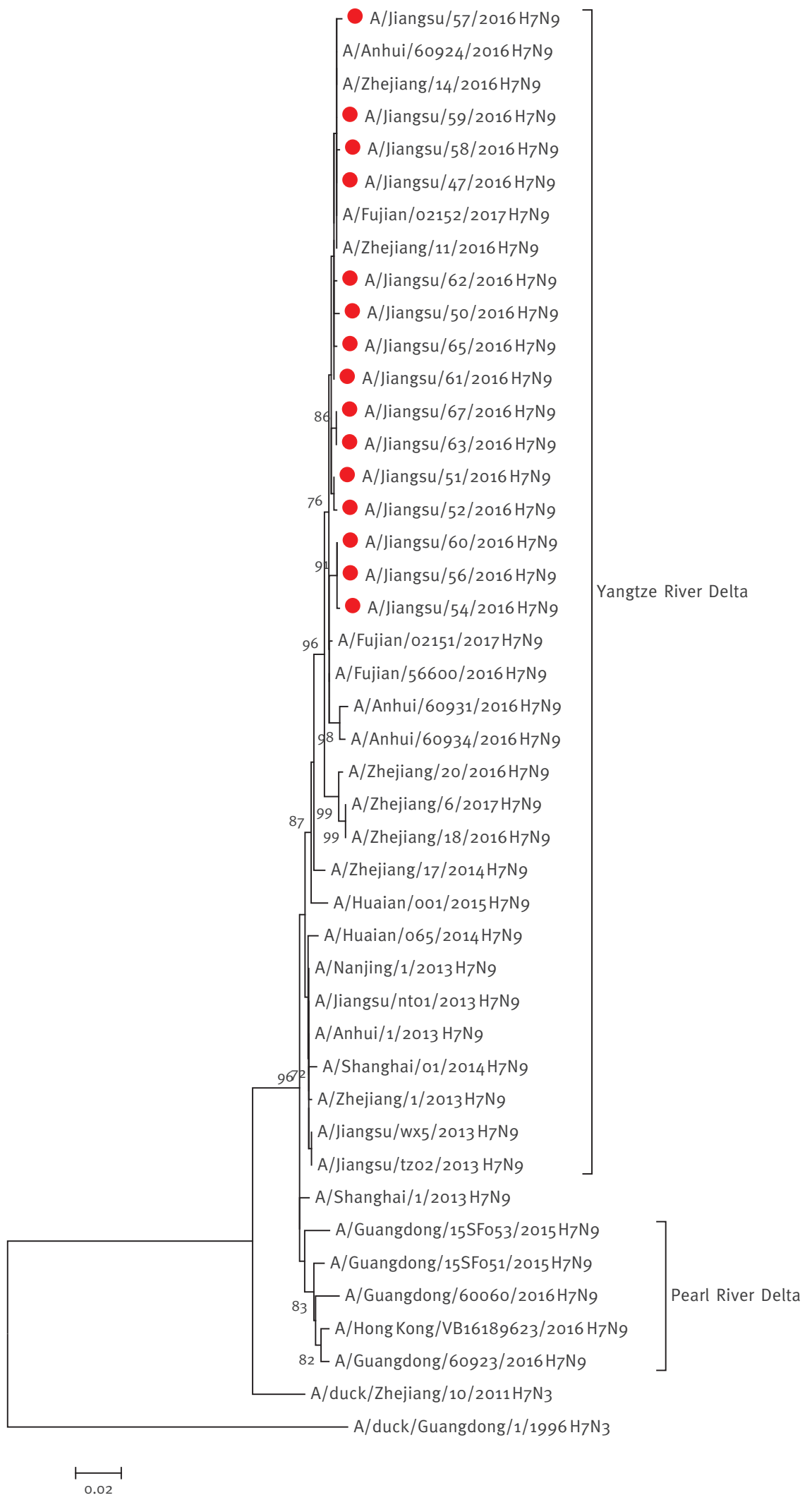

The phylogenetic tree of the HA1 coding nt sequences was generated by Molecular Evolutionary Genetic Analysis (MEGA) version 6.06 by neighbour-joining method with 1,000 bootstrap replicates; only bootstrap values over 70 are shown. Red circles indicate $\mathrm{H} 7 \mathrm{~N} 9 \mathrm{viruses}$ isolated from Jiangsu province, 2016. 
The proportion of severe infections as well as having poultry or poultry market exposure history remained high $(93.0 \%$ and $70.8 \%$, respectively) as in the previous waves. No significant differences were observed in patients' demographic characteristics (age, sex and $\mathrm{BMI}$ ), poultry or live poultry market exposure history, and proportion of severe infections and deaths between this wave and previous waves. However, patients' disease progression seemed to be accelerating during late waves. The median time intervals from onset of disease to intensive care unit (ICU) admission were around 7 days during the latest three waves, which was shorter than that of the first and the second wave (10 and 9 days, $p=0.048$ ). The median time interval from onset of disease to death was 13.5 days in the current wave, which was significantly shorter than that of previous four waves (15-28 days, $\mathrm{p}<0.0001)$ (Table 3).

Three clustered human infections with $\mathrm{H}_{7} \mathrm{~N} 9$ virus have been reported in previous waves in Jiangsu province, one in the first wave [11] and another two in the fourth (data not shown). During the fifth wave, another cluster of probable human-to-human transmission with laboratory evidence (viral sequence similarity>99.99\%) was reported in Suzhou city. The index case, a person aged in their mid-6os, visited live poultry markets regularly before getting ill. Three days after this case's onset of illness, a relative in their late 305 , took care of the index patient while in hospital, for a duration of three days, without taking any precautions. The relative had contact with sputum and the body of the index patient during this period and developed symptoms six days later. Two days after symptom onset, this secondary case was also admitted to hospital. Both patients were severely ill with diagnosis of pneumonia. The secondary patient recovered and was discharged from the hospital 25 days after their illness started, but the index patient died 17 days after disease onset.

Seasonal influenza activity peaked with $\mathrm{H}_{3} \mathrm{~N}_{2}$ being the predominant subtype during the same period (December 2016) in Jiangsu province. Similar to 2013, when we reported a patient co-infected with $\mathrm{H}_{7} \mathrm{~N} 9$ and $\mathrm{H}_{3} \mathrm{~N}_{2}$ virus [12], another such patient was identified in 2016 using real-time PCR. The patient, aged in their late 50 s lived in Suzhou, without chronic medical conditions and without seasonal influenza vaccination history. Three days prior to symptom onset, this person had visited a live poultry market together with their spouse and bought two chickens and one goose, without direct contact with these live poultry. Seven days after disease onset, the patient was admitted to hospital with severe pneumonia and died 13 days later. The spouse did not develop any symptoms.

\section{Environmental virus detection}

The environmental $\mathrm{H}_{7} \mathrm{~N} 9$ virus detection rate was found significantly elevated in Jiangsu during this wave as well ( $p<0.0001)$. It peaked at $18.5 \%$ (149/805) in December 2016 when most of the human infections of the ongoing fifth wave were reported, while the rate was only $3.1 \%(2 / 65), 3.1 \%(11 / 359)$ and $3.9 \%(22 / 561)$ during the same period of 2013, 2014 and 2015, respectively (Figure 1). In addition, an increased detection of $\mathrm{H}_{7} \mathrm{~N} 9$ virus in environmental samples collected during the summer was noted. The virus was not detected in August and September in 2014 and in September in 2015, but was detected in both August and September in 2016 (Figure 1).

\section{Meteorological impact}

We found that there were nine days with high risk minimum temperature (provincial mean) in December 2016 when most of the human infections were reported, which was significantly more than that of the same period in past three years (o, o and 4 in 2013, 2014 and 2015 respectively, $p<0.0001$ ). The number of days with high risk maximum temperature (provincial mean) in December 2016 was also significantly more than in the past 3 years (10 vs 5, 2 and 3 days respectively, $\mathrm{p}=0.028$ ). In November 2016 however, while the numbers of 'high risk' days were similar to that of December 2016 (10 days vs 9 days for minimum temperature, 12 days vs 10 days for maximum temperature), the environmental $\mathrm{H}_{7} \mathrm{~N} 9$ virus detection rate was remarkably lower than that of December (3.38\% vs $18.50 \%$ ), as was also the rate of human infections ( 9 in November vs 70 in December). The daily temperature data of January 2017 are unavailable at present.

\section{Viral analyses}

Whole genomes of fifteen $\mathrm{H}_{7} \mathrm{~N} 9$ strains, which were isolated from patients reported during this wave ( 1 in October, 2 in November and 12 in December 2016) in Jiangsu province, were sequenced and analysed. All the strains were from severely affected cities, that is, Suzhou ( $n=10$ total cases), Changzhou $(n=3)$ and Wuxi $(n=2)$. A phylogenetic tree of the HA genes of these strains was produced together with viruses isolated previously. The results showed that viruses isolated during the current wave shared the same ancestor as earlier viruses from 2013 to 2015, but clustered in an independent clade (Figure 3), which suggested that $\mathrm{H}_{7} \mathrm{~N} 9$ virus is continuously evolving.

Genetic characteristic analysis indicated that significant mutations have not occurred in these $\mathrm{H}_{7} \mathrm{~N} 9$ viruses. No substitutions were observed in two positions (G186V and Q226L) located in the receptor-binding sites of HA, indicating that the virus retains the ability to bind with both avian a2,3-sialic acid and human a2,6-sialic acid receptors. The $\mathrm{R} 294 \mathrm{~K}$ mutation in the neuraminidase (NA) protein, which is believed to confer resistance to NA inhibitors [13] was not observed in these isolates. Furthermore, the substitution of E627K in polymerase basic protein 2 (PB2) protein was not observed either, which indicates that viruses could not efficiently replicate in human [14]. 


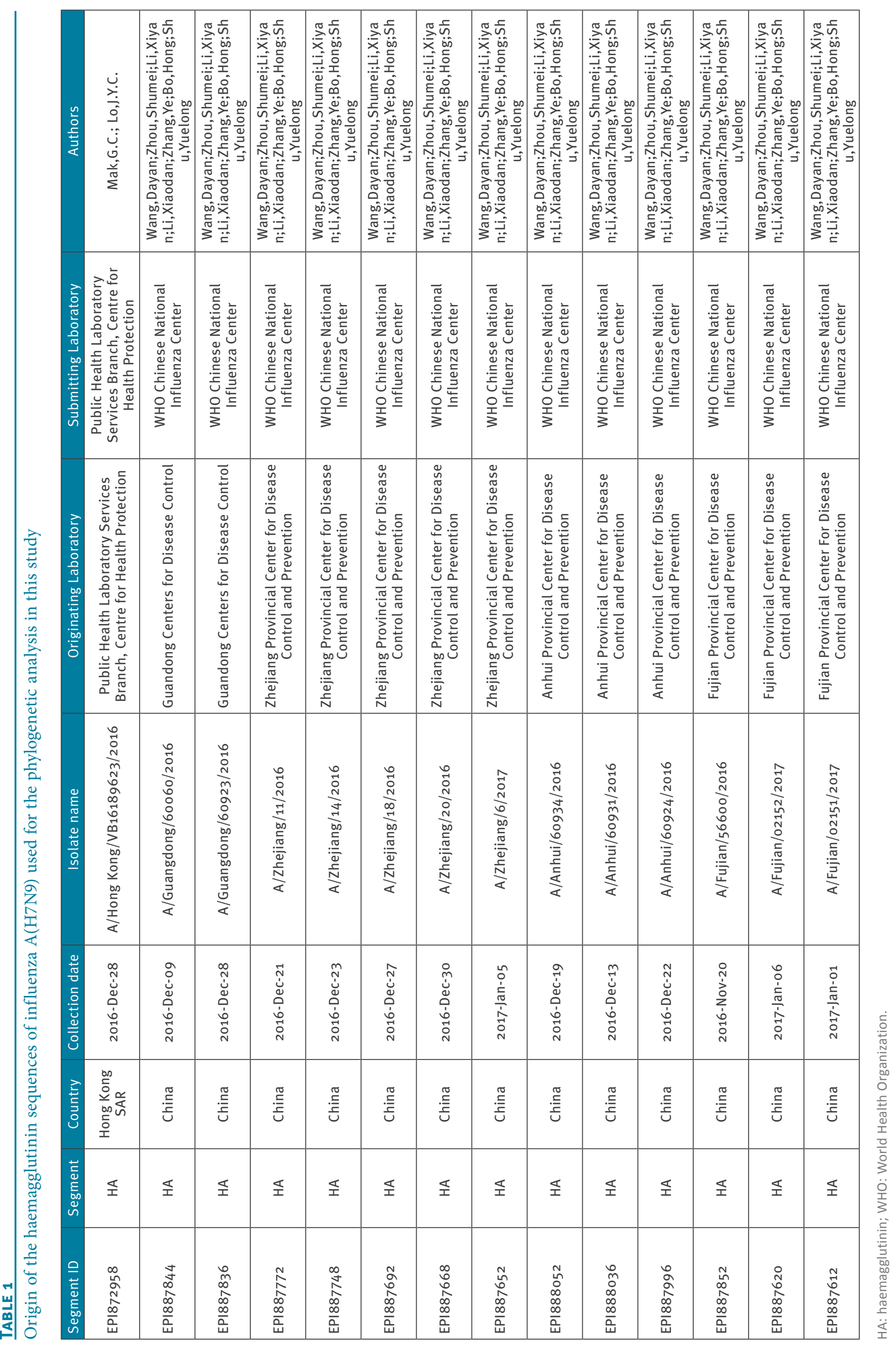


TABLE 2

Number of missing/total data of selected characteristics of H7N9 patients in Jiangsu province, March 2013-January 2017

\begin{tabular}{|l|c|c|c|c|c|}
\hline \multirow{2}{*}{$\begin{array}{l}\text { Selected } \\
\text { characteristics }\end{array}$} & \multicolumn{5}{|c|}{$\begin{array}{c}\text { Proportion of patients among the total missing } \\
\text { information on a characteristic }\end{array}$} \\
\cline { 2 - 6 } & $\begin{array}{c}\text { War } \\
\text { to Apr } \\
2013)\end{array}$ & $\begin{array}{c}\text { Wave 2 } \\
\text { (Dec } \\
\text { to May } \\
\text { to Mave }\end{array}$ & $\begin{array}{c}\text { Wo14 } \\
\text { (Oct } \\
\text { 2014 } \\
\text { to May } \\
2015)\end{array}$ & $\begin{array}{c}\text { Wave 4 } \\
\text { (Dec } \\
\text { 2015 } \\
\text { to May } \\
2016)\end{array}$ & $\begin{array}{c}\text { Wave 5 } \\
\text { (Oct } \\
\text { 2016 to } \\
\text { 31 Jan } \\
2017)\end{array}$ \\
\hline Age & $0 / 29$ & $0 / 27$ & $0 / 22$ & $0 / 26$ & $0 / 109$ \\
\hline Sex & $0 / 29$ & $0 / 27$ & $0 / 22$ & $0 / 26$ & $0 / 109$ \\
\hline BMI & $1 / 29$ & $0 / 27$ & $2 / 22$ & $1 / 26$ & $9 / 109$ \\
\hline $\begin{array}{l}\text { Poultry or live } \\
\text { poultry market } \\
\text { exposure }\end{array}$ & $2 / 29$ & $0 / 27$ & $2 / 22$ & $0 / 26$ & $15 / 109$ \\
\hline $\begin{array}{l}\text { Severe } \\
\text { infection }\end{array}$ & $2 / 29$ & $0 / 27$ & $2 / 22$ & $0 / 26$ & $9 / 109$ \\
\hline ICU admission & $2 / 29$ & $0 / 27$ & $2 / 22$ & $1 / 26$ & $33 / 109$ \\
\hline Death & $0 / 29$ & $2 / 27$ & $2 / 22$ & $1 / 26$ & $0 / 109$ \\
\hline $\begin{array}{l}\text { Number of } \\
\text { days from } \\
\text { onset of } \\
\text { disease to ICU } \\
\text { admission }\end{array}$ & $0 / 21$ & $0 / 20$ & $0 / 17$ & $0 / 20$ & $0 / 65$ \\
\hline $\begin{array}{l}\text { Number of } \\
\text { days from } \\
\text { onset of } \\
\text { disease to } \\
\text { death }\end{array}$ & $0 / 10$ & $0 / 13$ & $0 / 13$ & $0 / 11$ & $0 / 36$ \\
\hline
\end{tabular}

BMI: body mass index; ICU: intensive care unit.

\section{Discussion}

Jiangsu province is now experiencing the fifth wave of human infections with $\mathrm{H}_{7} \mathrm{~N}$, with a significantly elevated number of cases. Visiting live poultry markets is the main risk factor for $\mathrm{H}_{7} \mathrm{~N} 9$ infection for the public, due to poultry contact in this setting or environmental contamination $[15,16]$. The high $\mathrm{H}_{7} \mathrm{~N} 9$ virus detection rate in these sites may directly contribute to the elevated human $\mathrm{H}_{7} \mathrm{~N} 9$ infections. Therefore, live poultry market closures have been suggested as an effective method to control such infections $[17,18]$. Accordingly, several municipal governments in Jiangsu province, including Suzhou, Wuxi and Changzhou, have implemented temporary comprehensive live poultry market closures since December 2016. Subsequently, a significant decline in human infections has been observed in these cities/municipalities, as well as province-wide since January 2017 (Figure 1). The decrease was even more evident in February (data not shown).

Many meteorological factors, such as temperature, relative humidity $[7,19]$, specific humidity [20] and solar radiation [21], have been reported to influence influenza activity. As for $\mathrm{H}_{7} \mathrm{~N} 9$, both daily minimum and daily maximum temperatures have been reported to contribute significantly to human infection, but not relative humidity [22]. Other meteorological factors have not been reported. The overall impact of ambient temperature on human infection rates with $\mathrm{H}_{7} \mathrm{~N} 9$ may nevertheless also depend on the underlying level of environmental $\mathrm{H}_{7} \mathrm{~N} 9$ virus contamination, as exemplified by the results in November 2016, when although temperatures appeared to be permissive to human infection, low rates were observed, coinciding with low rates of environmental contamination. The environmental $\mathrm{H}_{7} \mathrm{~N} 9$ contamination rate could be influenced by multiple factors, such as $\mathrm{H}_{7} \mathrm{~N}$ 9 virus infection rate of poultry for sale, and the hygiene level of the live poultry market. The interaction and correlation between temperature and other factors and their impact on human infections need to be investigated further in future studies.

Antivirals such as oseltamivir were administrated to almost all of the $\mathrm{H}_{7} \mathrm{~N} 9$ patients in recent years in Jiangsu province. Furthermore, the time interval from onset of disease to antiviral administration is becoming shorter due to promoted sensitivity of clinicians. Clinicians also gained experiences in treatment, such as the rational use of ventilators and extracorporeal membrane oxygenation (ECMO). All of these measures are beneficial for the patients' clinical outcome. Nevertheless, an accelerated disease progression of $\mathrm{H}_{7} \mathrm{~N} 9$ patients during latest waves was still observed, which suggests that the viral pathogenicity might have become stronger. In addition, the increased detection rate of $\mathrm{H}_{7} \mathrm{~N} 9$ in environmental samples suggests that the virus might become more resistant to high ambient temperature. Although no significant mutations were observed in key functional loci of the isolates from the current wave in our preliminary analyses, further work still needs to be conducted in detail. For instance, changes in the length of the neuraminidase stalk region might impact virulence [23] and residues $41 \mathrm{~V}$ and/or $210 D$ in the nucleoprotein (NP) protein could enhance polymerase activities and potential replication at low temperature [24].

The pandemic potential of the $\mathrm{H}_{7} \mathrm{~N} 9$ virus needs to be closely watched. In humans, co-infection of this virus with seasonal influenza might provide reassortment opportunities for the emergence of a new pandemic virus. In addition, the continuous mutation and reassortment of $\mathrm{H}_{7} \mathrm{~N} 9$ with other avian influenza viruses lately resulted in the identification of $\mathrm{H}_{7} \mathrm{~N} 9$ isolates with characteristics of high pathogenicity to poultry, which was concerning for the poultry industry [25]. There is also a risk that $\mathrm{H}_{7} \mathrm{~N} 9$ might acquire better ability of spreading from poultry to ducks and wild birds, and thus be disseminated worldwide, threatening humans in a much wider geographical range [26-28]. Therefore, it is critical to control the transmission of $\mathrm{H}_{7} \mathrm{~N} 9$ virus in poultry to lower these risks. 
Comparisons of selected characteristics of H7N9 patients among five epidemic waves in Jiangsu province of eastern China, 2013-31 January 2017

\begin{tabular}{|c|c|c|c|c|c|c|}
\hline Selected characteristics & $\begin{array}{l}\text { Wave } 1 \\
\text { (Mar to Apr } \\
\text { 2013) } \\
n=29\end{array}$ & $\begin{array}{c}\text { Wave } 2 \\
\text { (Dec } 2013 \text { to May } \\
2014) \\
n=27\end{array}$ & $\begin{array}{c}\text { Wave } 3 \\
\text { (Oct 2014 to May } \\
2015) \\
n=22\end{array}$ & $\begin{array}{c}\text { Wave } 4 \\
\text { (Dec } 2015 \text { to May } \\
2016) \\
n=26\end{array}$ & $\begin{array}{c}\text { Wave } 5 \\
\text { (Oct 2016 to } 31 \text { Jan } \\
\text { 2017) } \\
n=109\end{array}$ & $\mathrm{~Pa}^{\mathrm{a}}$ \\
\hline Age, years, median, (IQRs) & $\begin{array}{c}54 \\
(35-70)\end{array}$ & $\begin{array}{c}53 \\
(42-66)\end{array}$ & $\begin{array}{c}57 \\
(50-68)\end{array}$ & $\begin{array}{c}53 \\
(41-63)\end{array}$ & $\begin{array}{c}58 \\
(46-66)\end{array}$ & 0.482 \\
\hline Proportion of male cases & $21 / 29$ & $20 / 27$ & $14 / 22$ & $18 / 26$ & $81 / 109$ & 0.860 \\
\hline BMI, median (IQRs) & $\begin{array}{c}22.94 \\
(22.17-24.16)\end{array}$ & $\begin{array}{c}23.44 \\
(21.97-26.12)\end{array}$ & $\begin{array}{c}23.85 \\
(22.49-26.55)\end{array}$ & $\begin{array}{c}24.01 \\
(21.23-26.37)\end{array}$ & $\begin{array}{c}24.22 \\
(22.49-26.12)\end{array}$ & 0.472 \\
\hline $\begin{array}{l}\text { Proportion of cases with } \\
\text { poultry or live poultry market } \\
\text { exposure }\end{array}$ & $14 / 20$ & $20 / 27$ & $15 / 20$ & $20 / 26$ & $63 / 89$ & 0.979 \\
\hline Proportion of severe infections & $23 / 28$ & $26 / 27$ & $18 / 20$ & $24 / 26$ & $93 / 100$ & 0.398 \\
\hline Proportions of ICU admission & $21 / 27$ & $20 / 27$ & $17 / 20$ & $20 / 25$ & $65 / 76$ & 0.665 \\
\hline Proportion of deaths & $10 / 29$ & $13 / 27$ & $13 / 22$ & $10 / 26$ & $36 / 109^{b}$ & 0.586 \\
\hline $\begin{array}{l}\text { Median number of days (IQR) } \\
\text { from onset of disease to ICU } \\
\text { admission }\end{array}$ & $\begin{array}{c}10 \\
(7-14)\end{array}$ & $\stackrel{9}{(8-11)}$ & $\begin{array}{c}7 \\
(6-9)\end{array}$ & $\begin{array}{c}7 \cdot 5 \\
(6-10)\end{array}$ & $\begin{array}{c}7 \\
(6-10)\end{array}$ & 0.048 \\
\hline $\begin{array}{l}\text { Medium number of days (IQR) } \\
\text { from onset of disease to death }\end{array}$ & $\begin{array}{c}28 \\
(20-45)\end{array}$ & $\begin{array}{c}24 \\
(20-38)\end{array}$ & $\begin{array}{c}15 \\
(13-23)\end{array}$ & $\begin{array}{c}22.5 \\
(13-42)\end{array}$ & $\begin{array}{c}13 \cdot 5 \\
(8-20.5)\end{array}$ & $<0.0001$ \\
\hline
\end{tabular}

BMI: body mass index; IQRs: interquartile ranges.

a Pearson chi-squared test was used for comparing proportions and Kruskal-Wallis H test was used for comparing medians.

b There were 36 patients still in hospital at the time of the study.

To avoid the possibility of further adaption to human of this virus, early identification of human infections with $\mathrm{H}_{7} \mathrm{~N} 9$ and early administration of neuraminidase inhibitors are critically needed. At present, the median time intervals from onset of disease to first medical consultation and from onset of disease to administration of neuraminidase inhibitors are two and six days, respectively. Efforts implementing effective rapid diagnostic kits in primary medical facilities, such as community clinics, could further promote the timeliness of diagnosis and antiviral therapy, as nearly half of the $\mathrm{H}_{7} \mathrm{~N} 9$ patients first seek medical services in these facilities.

Until now, older males still account for most of the $\mathrm{H}_{7} \mathrm{~N} 9$ patients. An overwhelming majority of the reported patients were severely infected and the overall case fatality remained above 30\%. Live bird markets are the most common sites for the public to contact birds or bird materials which might carry $\mathrm{H}_{7} \mathrm{~N} 9$ virus. With the continuous closures of live bird markets, the case number is expected to keep decreasing. In addition, the upcoming warmer weather would also deter the transmission of $\mathrm{H}_{7} \mathrm{~N}$ 9. However, we should be alert that $\mathrm{H}_{7} \mathrm{~N} 9$ cases might occur in areas where live bird market closures are not implemented, also because live poultry from places affected by $\mathrm{H}_{7} \mathrm{~N} 9$ and with market closures, may be transferred to these areas. A full investigation of the current wave of human infections with $\mathrm{H}_{7} \mathrm{~N} 9$ virus is still ongoing. This study presents timely preliminary results, including possible causes, which could help researchers in further detailed analyses.

\section{Acknowledgements}

We acknowledge the authors, originating and submitting laboratories of the sequences from GISAID's EpiFlu Database on which this research is based (see Table 1). All submitters of data may be contacted directly via the GISAID website www.gisaid.org.

The authors would like to thank Jiangsu Province Meteorological Bureau for providing meteorological data. The authors would also like to thank Mike He from Columbia Mailman School of Public Health for his assistance in language polishing.

X.H., X.Q., H.H., Q.D., H.Y., W.L., K.X., W.M. and C.B. were supported in part by Science \& Technology Demonstration Project for Emerging Infectious Diseases Control and Prevention (No. BE2015714), Key Medical Discipline (epidemiology, ZDXKA2016008) of Jiangsu Science \& Technology Project and National Science and Technology Major Project 
(2015ZX09101044). Xiang Huo was supported by the Research Foundation of National Health and Family Planning Commission of China (W201303). Wendong Liu was supported by the Jiangsu provincial science and technology special fund of clinical medicine (BL2014081) and the Jiangsu provincial natural science foundation (BK20151595). Changjun Bao was supported by the Natural Science Foundation of China (81373055), Jiangsu Provincial Medical Talent (ZDRCA2016032), the 10th Summit of Six Top Talents of Jiangsu Province (WS-2013-061) and the 5th ' 333 project' talents of Jiangsu province.

The opinions expressed in this article are the author's own and do not reflect the view of the Provincial Center for Diseases Control and Prevention of Jiangsu or the Provincial Health and Family Planning Commission of Jiangsu.

\section{Conflict of interest}

None declared.

\section{Authors' contributions}

C.B., X.H., L.C. and J.Z. conceived of the study and participated in the design of the study. X.Q., H.Y. and Y.X. performed the laboratory work and analyses. L.C., H.H, W.L., Q.D., K.X and W.M. carried out the epidemiological investigations and analyses. X.H. drafted the manuscript and all authors read and approved the final manuscript.

\section{References}

1. Zhou J, Wang D, Gao R, Zhao B, Song J, Qi X, et al. Biological features of novel avian influenza $A(\mathrm{H} 7 \mathrm{Ng})$ virus. Nature. 2013;499(7459):500-3. DOI: 10.1038/nature12379 PMID: 23823727

2. World Health Organization (WHO). Influenza at the human animal interface. Geneva: WHO; 2017. [Accessed 4 Feb 2017]. Available from: http://www.who.int/influenza/human animal interface/Influenza_Summary_IRA_HA_interface_01_16_2017 FINAL.pdf?ua $=1$

3. Zhou L, Ren R, Yang L, Bao C, Wu J, Wang D, et al. Sudden increase in human infection with avian influenza $\mathrm{A}\left(\mathrm{H}_{7} \mathrm{Ng}\right)$ virus in China, September-December 2016. Western Pac Surveill Response J. 2017;8(1). [Accessed 4 Feb 2017]. Available from: http://ojs.wpro.who.int/ojs/index.php/wpsar/article/ view/521/733

4. Xiang N, Li X, Ren R, Wang D, Zhou S, Greene CM, et al. Assessing Change in Avian Influenza $\mathrm{A}\left(\mathrm{H}_{7} \mathrm{~N} 9\right)$ Virus Infections During the Fourth Epidemic - China, September 2015-August 2016. MMWR Morb Mortal Wkly Rep. 2016;65(49):1390-4. DOI: 10.15585/mmwr.mm6549a2 PMID: 27977644

5. Wang L, Wang Y, Jin S, Wu Z, Chin DP, Koplan JP, et al. Emergence and control of infectious diseases in China. Lancet. 2008;372(9649):1598-605. DOI: 10.1016/S01406736(08)61365-3 PMID: 18930534

6. Qi X, Cui L, Yu H, Ge Y, Tang F. Whole-Genome Sequence of a Reassortant $\mathrm{H}_{5} \mathrm{~N} 6$ Avian Influenza Virus Isolated from a Live Poultry Market in China, 2013.Genome Announc. 2014;2(5):e00706-14. DOI: 10.1128/genomeA.00706-14 PMID: 25212611

7. Chan PK, Mok HY, Lee TC, Chu IM, Lam WY, Sung JJ. Seasonal influenza activity in Hong Kong and its association with meteorological variations.J Med Virol. 2009;81(10):1797-806. DOI: $10.1002 / j m v .21551$ PMID: 19697414

8. Larkin MA, Blackshields G, Brown NP, Chenna R, McGettigan $P A, M c W i l l i a m ~ H$, et al. Clustal $W$ and Clustal $X$ version 2.0. Bioinformatics. 2007;23(21):2947-8. DOI: 10.1093/ bioinformatics/btm404 PMID: 17846036

9. Tamura K, Stecher G, Peterson D, Filipski A, Kumar S. MEGA6: Molecular Evolutionary Genetics Analysis version 6.0.Mol Bio Evol. 2013;30(12):2725-9. DOI: 10.1093/molbev/mst197 PMID: 24132122

10. Cowling BJ, Jin L, Lau EH, Liao Q, Wu P, Jiang H, et al. Comparative epidemiology of human infections with avian influenza $\mathrm{A} \mathrm{H}_{7} \mathrm{~N} 9$ and $\mathrm{H}_{5} \mathrm{~N}_{1}$ viruses in China: a populationbased study of laboratory-confirmed cases. Lancet.
2013;382(9887):129-37. DOI: 10.1016/S0140-6736(13)61171-X PMID: 23803488

11. Qi X, Qian YH, Bao CJ, Guo XL, Cui LB, Tang FY, et al. Probable person to person transmission of novel avian influenza $\mathrm{A}\left(\mathrm{H}_{7} \mathrm{~N} 9\right)$ virus in Eastern China, 2013: epidemiological investigation. BMJ. 2013;347(augo6 2):f4752. DOI: 10.1136/bmj. f4752 PMID: 23920350

12. Zhu Y, Qi X, Cui L, Zhou M, Wang H. Human co-infection with novel avian influenza $A H_{7} N_{9}$ and influenza $A H_{3} N_{2}$ viruses in Jiangsu province, China.Lancet. 2013;381(9883):2134. DOI: 10.1016/So140-6736(13)61135-6 PMID: 23769236

13. Hu Y, Lu S, Song Z, Wang W, Hao P, Li J, et al. Association between adverse clinical outcome in human disease caused by novel influenza A H7No virus and sustained viral shedding and emergence of antiviral resistance. Lancet. 2013;381(9885):2273-9. DOI: 10.1016/S0140-6736(13)61125-3 PMID: 23726392

14. Labadie K, Dos Santos Afonso E, Rameix-Welti MA, van der Werf S, Naffakh N. Host-range determinants on the PB2 protein of influenza A viruses control the interaction between the viral polymerase and nucleoprotein in human cells.Virology. 2007;362(2):271-82. DOI: 10.1016/j.virol.2006.12.027 PMID: 17270230

15. Liu B, Havers F, Chen E, Yuan Z, Yuan H, Ou J, et al. Risk factors for influenza $\mathrm{A}(\mathrm{H} 7 \mathrm{~N} 9)$ disease--China, 2013. Clin Infect Dis. 2014;59(6):787-94. DOI: 10.1093/cid/ciu423 PMID: 24928293

16. Zhou J, Wu J, Zeng X, Huang G, Zou L, Song Y, et al. Isolation of $\mathrm{H}_{5} \mathrm{~N} 6, \mathrm{H}_{7} \mathrm{~N}_{9}$ and $\mathrm{H}_{9} \mathrm{~N}_{2}$ avian influenza A viruses from air sampled at live poultry markets in China, 2014 and 2015. Euro Surveill. 2016;21(35):30331. DOI: 10.2807/1560-7917. ES.2016.21.35.30331 PMID: 27608369

17. He Y, Liu P, Tang S, Chen Y, Pei E, Zhao B, et al. Live poultry market closure and control of avian influenza $A\left(\mathrm{H}_{7} \mathrm{~N} 9\right)$, Shanghai, China. Emerg Infect Dis. 2014;20(9):1565-6. DOI: 10.3201/eid2009.131243 PMID: 25148432

18. Yuan J, Lau EH, Li K, Leung YH, Yang Z, Xie C, et al. Effect of Live Poultry Market Closure on Avian Influenza $\left.\mathrm{A}_{(\mathrm{H}} \mathrm{H}_{9}\right)$ Virus Activity in Guangzhou, China, 2014. Emerg Infect Dis. 2015;21(10):1784-93. DOI: 10.3201/eid2110.150623 PMID: 26402310

19. Lowen AC, Mubareka S, Steel J, Palese P. Influenza virus transmission is dependent on relative humidity and temperature.PLoS Pathog. 2007;3(10):1470-6. DOI: 10.1371/ journal.ppat.0030151 PMID: 17953482

20. Soebiyanto RP, Clara W, Jara J, Castillo L, Sorto OR, Marinero $S$, et al. The role of temperature and humidity on seasonal influenza in tropical areas: Guatemala, El Salvador and Panama, 2008-2013. PLoS One. 2014;9(6):e100659. DOI: 10.1371/journal.pone.0100659 PMID: 24956184

21. Charland KM, Buckeridge DL, Sturtevant JL, Melton F, Reis $\mathrm{BY}$, Mandl KD, et al. Effect of environmental factors on the spatio-temporal patterns of influenza spread. Epidemiol Infect. 2009;137(10):1377-87. DOI: 10.1017/So950268809002283 PMID: 19296868

22. Zhang Y, Feng C, Ma C, Yang P, Tang S, Lau A, et al. The impact of temperature and humidity measures on influenza A ( $\left.\mathrm{H}_{7} \mathrm{~N} 9\right)$ outbreaks-evidence from China. Int J Infect Dis. 2015;30:122-4. DOI: 10.1016/j.ijid.2014.11.010 PMID: 25462179

23. Bi Y, Xiao H, Chen Q, Wu Y, Fu L, Quan C, et al. Changes in the Length of the Neuraminidase Stalk Region Impact $\mathrm{H}_{7} \mathrm{~N} 9$ Virulence in Mice. J Virol. 2015;90(4):2142-9. DOI: 10.1128/ JVI.02553-15 PMID: 26656694

24. Zhu W, Zou X, Zhou J, Tang J, Shu Y. Residues $41 \mathrm{~V}$ and/or $210 D$ in the NP protein enhance polymerase activities and potential replication of novel influenza $\left(\mathrm{H}_{7} \mathrm{~N} 9\right)$ viruses at low temperature.Virol J. 2015;12(1):71. DOI: 10.1186/s12985-0150304-6 PMID: 25940512

25. World Health Organization (WHO). Human infection with avian influenza $\mathrm{A}\left(\mathrm{H}_{7} \mathrm{~N} 9\right)$ virus - China. Geneva: WHO; 2017. [Accessed on 6 Mar 2017]. Available from: http://www.who.int/ csr/don/27-february-2017-ah7n9-china/en/

26. Claes F, Morzaria SP, Donis RO. Emergence and dissemination of clade 2.3.4.4 $\mathrm{H}_{5} \mathrm{Nx}$ influenza viruses-how is the Asian HPAI $\mathrm{H}_{5}$ lineage maintained.Curr Opin Virol. 2016;16:158-63. DOI: 10.1016/j.coviro.2016.02.005 PMID: 26991931

27. Yu Z, Gao X, Wang T, Li Y, Li Y, Xu Y, et al. Fatal H5N6 Avian Influenza Virus Infection in a Domestic Cat and Wild Birds in China. Sci Rep. 2015;5:10704. DOI: 10.1038/srep10704 PMID: 26034886

28. Sun H, Pu J, Hu J, Liu L, Xu G, Gao GF, et al. Characterization of clade 2.3 .4 .4 highly pathogenic $\mathrm{H}_{5}$ avian influenza viruses in ducks and chickens. Vet Microbiol. 2016;182:116-22. DOI: 10.1016/j.vetmic.2015.11.001 PMID: 26711037 
License and copyright

This is an open-access article distributed under the terms of the Creative Commons Attribution (CC BY 4.0) Licence. You may share and adapt the material, but must give appropriate credit to the source, provide a link to the licence, and indicate if changes were made.

This article is copyright of the authors, 2017. 